\title{
A Study Case on Estimation of Soil Loss and Sediment Yield in Curtin University, Malaysia
}

\author{
Hui Yee Ngieng ${ }^{1 *}$, Leong Kong Yong ${ }^{1}$, Striprabu Strimari ${ }^{2}$ \\ ${ }^{1}$ Environmental Engineering Program, Faculty of Engineering and Science, Curtin University Malaysia, CDT 250, Miri \\ 98009, Malaysia. \\ ${ }^{2}$ Geotechnical \& Slope Engineering Unit, Jabatan Kerja Raya Sarawak, Wisma Saberkas, Kuching 93626, Malaysia. \\ * Correspondence: dorisnhy668899@gmail.com
}

SUBMITTED: 15 July 2021; REVISED: 31 August 2021; ACCEPTED: 1 September 2021

\begin{abstract}
Because of human activities, soil erosion has been one of the most concerning issues in Malaysia in the past decades. This study aimed to estimate the amount of soil loss and sediment yield at Curtin University, Malaysia by using the Revised Universal Soil Loss Equation (RUSLE) and the Modified Universal Soil Loss Equation (MUSLE), respectively. The parameters of RUSLE include rainfall erosivity factor (R), soil erodibility factor (K), slope length factor (L), slope steepness factor (S), cover-management factor (C) and support practice factor (P). The rainfall data (10 years) from the Sarawak Meteorological Department was used to determine the R-factor. The K-factor was determined by sieve analysis, hydrometer analysis, the Standard Proctor Test (SPT), and organic content testing. The L-and S-factors were performed by measuring on site and using Google Earth. The C-and P-factors were based on the ground surface cover condition (bare soil in this study). In the MUSLE, the runoff factor comprises $\mathrm{V}$ and $\mathrm{Qp}$, while the other parameters are the same as in the RUSLE. The runoff depth, V, is equivalent to the rainfall intensity. Rainfall intensities were recorded by using a rain gauge. The highest rainfall intensity was used for runoff depth. The Rational method has been utilized to calculate $Q_{p}$. The amount of soil loss estimated was 119.97 tons/ha/year and the sediment yield amount estimated was 0.76 ton/storm event in Curtin University, Malaysia.
\end{abstract}

KEYWORDS: Soil loss; sediment yield; soil erosion; RUSLE; MUSLE

\section{Introduction}

Soil erosion is one of the global environmental issues in Asian countries. Due to the development trend in Asia, many studies are focused on soil erosion topics. China, India, and Indonesia are the top three Asian countries experiencing high soil erosion, with an erosion area of $470,000 \mathrm{~km}^{2}, 200,000 \mathrm{~km} 2$, and $76,000 \mathrm{~km}^{2}$, respectively. The main reason for soil erosion in these countries is due to improper control practices in agriculture [1]. The amount of soil loss and sediment yield from the mine tailing dumps in Samgwang mine, Korea, was estimated at around 75,351 tons/yr and 40,188 tons/yr, respectively [2]. Rapid development in Malaysia promotes policies for agriculture and tourism, affecting the land cover of the Cameron Highlands and bringing soil erosion and water pollution problems to the upland region [3]. 
According to a study in Ringlet Reservoir Cameron Highlands, the estimation of sediment yield in a year is around 0.28 million $\mathrm{m}^{3}$ (1997) and 0.33 million $\mathrm{m}^{3}$ (2006) [4]. In natural phenomena, the subsurface of land is being eroded by physical forces such as precipitation, flows of water, gravity, wind and others [5]. The rate of soil erosion increases through anthropogenic activities such as urbanization, deforestation, land clearing and agricultural activities [6-8]. During a downpour, the soil becomes fully saturated, resulting in surface runoff, which then increases the velocity and shear stress exerted on the soil. A large number of raindrops have higher terminal velocity and energy. Thus, the soil particles dislodge from the soil surface due to the impact of raindrops hitting and splashing on the soil surface. When surface runoff overcomes the force grasping soil particles, the soil particles move from their original position or separatione from the soil surface [9]. The surface runoff brings away the topsoil, contributing to the loss of soil fertility and land degradation problems [10,11]. The soil particles have been washed by the surface runoff down the slope and into the river [12]. Larger sized soil particles would be deposited on the downslope, whilst smaller sized soil particles would be washed into the river. The movement of sediment in the river is because the critical shear stress of sediment in the riverbed is smaller than the induced shear stress of river flow. Sediment breaks into smaller particles or moves from its original place when an external force is exerted on the sediment [13]. Since the industrialization revolution, deforestation has been done widely for the quest of development, urbanization and agricultural [14]. Human activities such as mining, agriculture, overgrazing and construction accelerate the soil erosion process $[15,16]$. These anthropogenic activities affected approximately 1,964 million hectares of soils, where 1,903 million hectares of eroded soils were related to water erosion and the remaining was due to wind erosion [17]. It is estimated that the rate of soil erosion will increase annually, and this would be one of the major environmental issues for a few decades [18]. The soil particles are detached from the slope and carried by surface runoff into water bodies such as streams, lakes, and rivers, and cause the water bodies to become murky, which destroys freshwater sources, affecting the quality of water and aquatic life [19]. Sedimentation occurs when the soil particles settle down to the bottom of the river and cause the level of the riverbed to increase, subsequently causing flash floods during heavy rainfall [20]. This study aimed to estimate the amount of soil loss and sediment yield at Curtin University Malaysia in Miri, Sarawak. The RUSLE and MUSLE were used to estimate the amount of soil loss and sediment yield, respectively.

\section{Methods}

\subsection{Location}

Malaysia is located in the Equatorial region, which has a tropical climate that is hot and humid throughout the year [21]. It is surrounded by the South China Sea and the Indian Ocean, and experiences two monsoon seasons: the Northeast Monsoon (November to March) and the Southwest Monsoon (May to September). The Northeast Monsoon brings more rainfall and generates more surface runoff as compared to the Southwest Monsoon [22]. As a result, the amount of soil loss and sediment yield is higher during the Northeast Monsoon [23]. In this study, a construction site with a project area size of $9,382.19 \mathrm{~m}^{2}(0.94 \mathrm{ha})$ at Curtin University Malaysia was selected as shown in Figure 1. Curtin University, Malaysia is located in Miri town, which is part of Northern Sarawak, Malaysia at Latitude $4^{\circ} 30^{\prime} \mathrm{N}$ and Longitude $114^{\circ} 01^{\prime}$ 
E. Miri experiences copious rainfall throughout the year. A set of rainfall data from 2009 to 2018 was obtained from the nearest meteorological station, which is located at Miri Airport, Sarawak. The annual total rainfall amount varies from $2,072.9 \mathrm{~mm}$ to $3,386.1 \mathrm{~mm}$.

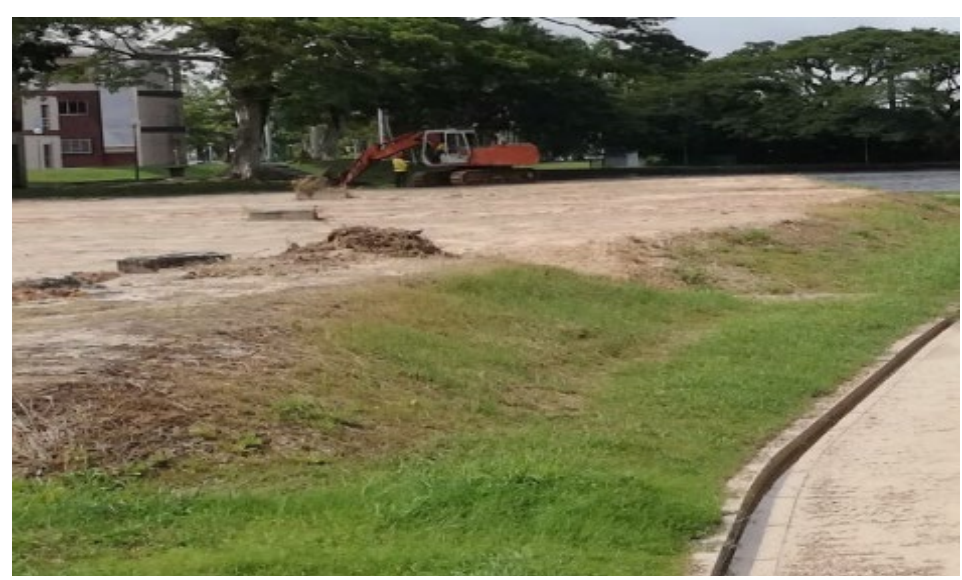

Figure 1. Construction Site at Curtin University Sarawak

Experimental work was carried out to determine the variables in the RUSLE and MUSLE, such as rainfall harvesting, sieve analysis, Standard Proctor Test (SPT), Hydrometer test, slope length, and slope gradient measurements.

\subsection{Soil Loss Estimation - Revised Universal Soil Loss Equation (RUSLE)}

The soil loss is varied over space and time because of the relationship between the variables of RUSLE [24]. The RUSLE model is expressed as A = R.L.K.S.C.P, where A is defined as the rate of soil loss expressed in unit tons/ha/yr; $\mathrm{R}$ represents rainfall erosivity factor expressed in unit MJ.mm/ha/h/year; K represents soil erodibility factor expressed in unit ton.hr/MJ.mm; L represents slope length factor (dimensionless); $\mathrm{S}$ represents slope steepness factor (dimensionless); $\mathrm{C}$ represents cover-management factor (dimensionless) and $\mathrm{P}$ represents support practice factor (dimensionless) [25].

\subsubsection{Runoff Erosivity Factor (R)}

The rainfall data from 2009 to 2018 was obtained from the meteorological station located at Miri Airport, Sarawak. The data is necessary to calculate the $\mathrm{R}$ value and the equation recommended is shown in $R_{a n n}=\left[4.17 \times \sum_{i=1}^{12}\left(\frac{P_{i}{ }^{2}}{P}\right)\right]-152$ [26]. Where $P_{i}$ denotes the mean value of rainfall data in month $\mathrm{i}$ in millimetres $(\mathrm{mm}), \mathrm{P}$ denotes the mean value of rainfall data in year in $\mathrm{mm}$, and Rann denotes the annual mean value of $\mathrm{R}$.

\subsubsection{Soil Erodibility Factor $(K)$}

The soil erodibility nomograph developed by Renard et. al. was used to obtain the soil erodibility factor $(\mathrm{K})$. The percentage of silt, very fine sand and organic matter were analysed through experiment. The soil structure code and permeability code of soil were determined. Grain size distribution (GSD) analysis coupled with USDA texture soil classification were carried out to identify the soil type [27]. Grain size distribution analysis can be divided into sieve analysis and hydrometer analysis. The larger size of soil particles $(>0.075 \mathrm{~mm})$ can be easily separated by sieve analysis, whereas the smaller size of soil particles $(0.075 \mathrm{~mm})$ can be 
analyzed by hydrometer based on ASTM D422 (Table 1). Distilled water (1 L) was prepared and immersed in a $152 \mathrm{H}$ hydrometer to obtain meniscus correction, $\mathrm{C}_{\mathrm{m}} .4 \%$ of sodium hexametaphosphate, $\left(\mathrm{NaPO}_{3}\right)_{6}$ (disperging agent) was prepared by dissolving $40 \mathrm{~g}$ of $\left(\mathrm{NaPO}_{3}\right)_{6}$ in $1 \mathrm{~L}$ of distilled water in a graduated cylinder to have a $\left(\mathrm{NaPO}_{3}\right)_{6}$ solution. A $100 \mathrm{~mL}$ of $\left(\mathrm{NaPO}_{3}\right)_{6}$ solution mixed with $1 \mathrm{~L}$ of distilled water using a graduated cylinder and a $152 \mathrm{H}$ hydrometer was immersed in the solution to obtain the value of dispersing agent correction, $\mathrm{C}_{\mathrm{a}}$. The suspension fliud was poured into a graduated cylinder and was filled with distilled water up to $1 \mathrm{~L}$. Then graduated cylinder was shake the for 1 minute with a tight lid. The hydrometer reading and suspension fluid temperature $\left(\mathrm{C}_{\mathrm{t}}\right)$ were monitored for 24 hours.

Table 1. Equations of Different Experiments to Identify K

\begin{tabular}{lc}
\hline Experiment & Equations \\
\hline $\begin{array}{l}\text { Hydrometer } \\
\text { analysis }\end{array}$ & $R_{h}=R^{\prime}{ }_{h}+C_{m}$ \\
$R_{c}=R_{h}+C_{t}-C_{a}$ \\
$P=\frac{R_{c} \alpha}{M_{d r y}} \times 100 \times \frac{M_{<0.075 m m}}{M_{t}}$ \\
$D=k \sqrt{\frac{L(\mathrm{~cm})}{t(\mathrm{~min})}}$
\end{tabular}

Where, $R_{h}{ }_{h}$ is hydrometer reading; $C_{m}$ is meniscus correction; $C_{a}$ is dispersing agent; $R_{c}$ is hydrometer reading; $\mathrm{P}$ is corrected percentage passing; $\mathrm{M}_{\mathrm{dry}}$ is dry mass of hydrometer test sample; $\mathrm{M}_{<0.075 \mathrm{~mm}}$ is dry mass of soil sample with size less than $0.075 \mathrm{~mm}$ and $\mathrm{M}_{\mathrm{t}}$ is the total mass of dry soil sample.

$$
\begin{gathered}
\text { moisture content, } m_{c}(\%)=\frac{M_{w}}{M_{s}} \times 100 \%=\frac{M_{4}-M_{5}}{M_{5}-M_{3}} \times 100 \% \\
\text { bulk unit weight, } \gamma_{b}\left(\frac{\mathrm{kN}}{m^{3}}\right)=\frac{M_{m s}(g)}{V} \times 9.8066 \\
\text { dry unit weight, } \gamma_{d}\left(\frac{\mathrm{kN}}{m^{3}}\right)=\frac{\gamma_{b}}{1+\frac{m_{c}}{100}}
\end{gathered}
$$

Where, $M_{3}$ is mass of moisture can; $M_{4}$ is mass of moisture can with moist soil; $M_{5}$ is mass of moisture can with dry soil; $M_{m s}$ is mass of moist soil' $V$ is the volume of proctor mould; $M_{c}$ is moisture content; $\gamma_{\mathrm{b}}$ is bulk unit weight in $\mathrm{kN} / \mathrm{m}^{3}$.

Organic content test

$$
\begin{gathered}
M_{d t s}=M_{c d t s}-M_{c} \\
M_{a}=M_{c a}-M_{c} \\
A_{c}=\frac{M_{a}}{M_{d t s}} \times 100 \% \\
O_{c}=100 \%-A_{c}
\end{gathered}
$$

Where, $M_{d t s}$ is mass of dry test soil; $M_{c d t s}$ is mass of crucible with dry test soil; $M_{c}$ is mass of crucible; $M_{a}$ is mass of ash; $M_{c a}$ is mass of crucible with ash; $A_{c}$ is ash content; $O_{c}$ is organic matter content. 
The soil structure and permeability code were identified according to the type of soil. A Standard Proctor Test (SPT) was carried out to determine the maximum dry density and optimum moisture content of soil samples by referring to ASTM D698-12e2 [28,29]. The soil sample $(3 \mathrm{Kg})$ was dried in an oven at $110^{\circ} \mathrm{C}$ for 24 hours and was sieved by using a siever $(4.75 \mathrm{~mm})$. In the $1^{\text {st }}$ test, $150 \mathrm{~g}$ of water was added and mixed thoroughly with the dried soil sample in a tray. The mass of the proctor mould with base, $\mathrm{W} 1$, with a volume of $1000 \mathrm{~cm}^{3}$, was recorded. The proctor mould was joined to the base and extension collar. The soil in the proctor mould was divided into 3 layers and each layer was compacted with 25 blows by using $2.5 \mathrm{~kg}$ of compaction rammer. The overall height of the three soil layers must slightly surpass the extension collar. Then the extension collar was removed and the soil exceeding the extension collar was removed by using a straight edge to make sure the compacted soil was the same level as the top of the mould. The mass of proctor mould with the base plate filled with moist soil, W2, was recorded. The base plate of the proctor mold was removed. Compacted soil was collected by using a spatula and put in a moisture can. The mass of moisture that can be found in moist soil, W4, was recorded. Moisture can be dried in an oven for 24 hours. The mass of moisture that can be found in dry soil, W5, was recorded. The remaining soil was broken off and mixed with the remaining soil in the tray for the next test. The procedures above were repeated for another 3 tests.

An organic content test was conducted to identify the percentage of organic matter in the soil according to ASTM D2974. A dried soil sample was prepared. The mass of the empty crucible and the crucible filled with dry test soil were recorded. The crucibles filled with dry test soil were placed in a furnace at a $440^{\circ} \mathrm{C}$ temperature for 24 hours. The test soil was completely ash. The crucibles with ash were removed from the furnace and cooled down to room temperature. Then, the mass of crucibles with ash was recorded. The mass of dry test soil, the mass of ash, ash content, and organic matter content were calculated by using equations.

\subsubsection{Slope Length Factor (L) \& Slope Steepness Factor (S)}

The combination of slope length factor (L) and slope steepness factor (S) is expressed as the topography of the slope, which gives the value scaled to the RUSLE experimental plot with a $72.6 \mathrm{ft}$ slope length and 9\% slope gradient. In the case of a steep slope, the length should be defined in the horizontal distance for RUSLE calculation, where the horizontal distance starts from the point where the origin of overland flow is reduced enough to start the deposition process or the surface runoff enters a well-defined channel [30]. Slope steepness can be defined by slope gradient effects on soil erosion [4,31]. In this study, the height and slope length were measured on site by using Google Earth and measuring tape. Figure 2 indicates the method to identify the slope gradient, slope angle, height and horizontal slope length. and are the equations to calculate $\mathrm{L}$ and $\mathrm{S}$. The equation of slope gradient is shown as follows:

$S=\frac{h}{\lambda} \times 100 \%$

$\theta=\tan ^{-1}\left(\frac{h}{\lambda}\right)$

$\beta=\frac{\sin \theta \div 0.0896}{3.0(\sin \theta)^{0.8}+0.56}$ 
$m=\frac{\beta}{(1+\beta)}$

Where, $\mathrm{L}$ is slope length; $\mathrm{S}$ is slope gradient; $\theta$ is slope angle; $\beta$ is a constant; $\mathrm{m}$ is exponent; $\mathrm{h}$ is height; $\lambda$ is horizontal slope length.

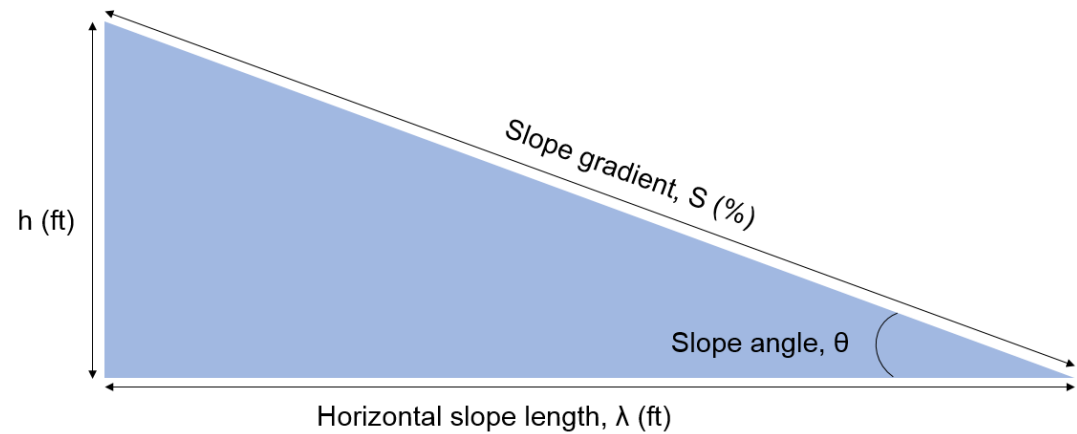

Figure 2. Slope Gradient, Slope Angle, Height and Horizontal Slope Length

\subsubsection{Cover Management Factor (C) and Support Practice Factor (P)}

The cover management factor value was was standardized by the Ministry of Natural Resources and Environment Malaysia. In this study, the ground surface of the construction site at Curtin University Malaysia was bare soil and generally flat (no support practice), therefore both Cand P-factors were 1.0.

\subsection{Sediment Yield Estimation - Modified Universal Soil Loss Equation (MUSLE)}

MUSLE model was selected to estimate the sediment yield, which can be expressed as $S=11.8\left(V \times Q_{P}\right)^{0.56}$.K.L.S.C.P. The V represents runoff depth in unit feet $(\mathrm{ft})$ and $\mathrm{Q}_{\mathrm{p}}$ represents event peak discharge in unit cubic feet per second $\left(\mathrm{ft}^{3} / \mathrm{s}\right)$, while the variables $\mathrm{K}, \mathrm{L}$, $\mathrm{C}$ and $\mathrm{P}$ are the same as the RUSLE equation. Runoff depth (V) is equivalent to the height of rainwater collected in raingauge of each rainfall event. Ten rainfall events were collected and the rainfall depths were recorded from Jan to April 2021 at the construction site in Curtin University, Malaysia. The highest reading was selected to estimate the amount of sediment yield. The $\mathrm{Q}_{\mathrm{p}}$ can be determined by using the Rational Method, $Q=C I A$. Where, $\mathrm{C}$ is runoff coefficient, I is rainfall intensity in in/hr and A is the catchment area in acres.

\section{Results and Discussion}

\subsection{Soil Loss Estimation}

\subsubsection{Runoff Erosivity Factor (R)}

The average monthly rainfall in 10 years (2009-2018) was obtained from the Malaysia Meteorological Department (Sarawak Branch) and used to estimate the R-factor (Figure 3). Within the period of 10 years, the minimum R-factor was determined to be 756.12 $\mathrm{MJ} . \mathrm{mm} / \mathrm{ha} /$ year in 2016, whereas the maximum R-factor was determined to be $1,717.18$ 
MJ.mm/ha/yr in 2009. The average R-factor for 10 years was estimated at $1,176.13$ MJ.mm/ha/yr (Table 2).

\begin{tabular}{|c|c|c|c|c|c|c|c|c|c|c|c|c|c|}
\hline \multicolumn{4}{|c|}{ Records Of Monthly Total Rainfall Amount } & \multicolumn{10}{|c|}{ Unit : Millimetre } \\
\hline \multicolumn{14}{|c|}{ Station : Miri Airport } \\
\hline \multirow{2}{*}{\multicolumn{14}{|c|}{$\begin{array}{l}\text { Lat. : } 04 \text { Deg. 20' N } \\
\text { Long. : } 113 \text { Deg. 59' E }\end{array}$}} \\
\hline \multirow{2}{*}{\multicolumn{14}{|c|}{ Height Above M.S.L. : $17.0 \mathrm{M}$}} \\
\hline & & & & & & & & & & & & & \\
\hline $\begin{array}{l}\text { Month / } \\
\text { Year }\end{array}$ & Jan & Feb & Mar & Apr & May & Jun & Jul & Aug & Sep & Oet & Nov & Dec & Annual \\
\hline 2009 & 928.2 & 241.2 & 197.4 & 255.6 & 65.6 & 123.6 & 124.0 & 162.0 & 189.6 & 262.2 & 249.2 & 453.6 & 3252.2 \\
\hline 2010 & 273.4 & 7.8 & 45.4 & 159.8 & 332.7 & 211.0 & 407.2 & 342.6 & 404.8 & 287.8 & 338.0 & 276.0 & 3086.5 \\
\hline 2011 & 669.9 & 308.7 & 330.4 & 175.6 & 225.6 & 282.2 & 157.8 & 165.8 & 120.4 & 118.2 & 313.4 & 378.4 & 3246.4 \\
\hline 2012 & 280.8 & 204.4 & 316.4 & 141.0 & 136.6 & 168.0 & 160.8 & 170.6 & 80.8 & 339.4 & 463.2 & 233.8 & 2695.8 \\
\hline 2013 & 191.0 & 339.0 & 131.8 & 197.0 & 220.8 & 101.8 & 168.0 & 249.0 & 317.9 & 254.3 & 260.4 & 694.0 & 3125.0 \\
\hline 2014 & 506.2 & 29.0 & 126.0 & 97.2 & 248.4 & 66.2 & 101.4 & 179.8 & 96.0 & 307.4 & 354.2 & 261.4 & 2373.2 \\
\hline 2015 & 652.8 & 122.6 & 15.8 & 182.2 & 81.4 & 259.4 & 216.0 & 169.4 & 164.8 & 150.6 & 306.2 & 313.6 & 2634.8 \\
\hline 2016 & 70.6 & 81.4 & 85.8 & 164.8 & 228.8 & 127.6 & 265.0 & 164.2 & 108.4 & 310.9 & 339.4 & 126.0 & 2072.9 \\
\hline 2017 & 207.6 & 214.0 & 186.2 & 110.2 & 341.0 & 164.2 & 126.0 & 365.6 & 234.2 & 429.4 & 333.0 & 428.8 & 3140.2 \\
\hline 2018 & 485.4 & 343.0 & 208.2 & 247.8 & 237.2 & 255.6 & 258.2 & 159.0 & 303.4 & 292.4 & 179.2 & 416.7 & 3386.1 \\
\hline
\end{tabular}

Figure 3. Rainfall Data of Sarawak, Malaysia from 2009 to 2018.

Table 2. R Factor From 2009 To 2018

\begin{tabular}{ccccccccccc}
\hline Year & $\mathbf{2 0 0 9}$ & $\mathbf{2 0 1 0}$ & $\mathbf{2 0 1 1}$ & $\mathbf{2 0 1 2}$ & $\mathbf{2 0 1 3}$ & $\mathbf{2 0 1 4}$ & $\mathbf{2 0 1 5}$ & $\mathbf{2 0 1 6}$ & $\mathbf{2 0 1 7}$ & $\mathbf{2 0 1 8}$ \\
\hline & & & & & & & & & \\
$\begin{array}{c}\mathbf{R}_{\text {ann }}(\mathbf{M J} \\
\mathbf{m m ~ h a}^{-1} \\
\left.\mathbf{y r}^{-1}\right)\end{array}$ & 1717.18 & 1169.21 & 1308.29 & 982.46 & 1278.61 & 1057.95 & 1218.32 & 756.12 & 1126.12 & 1147.06 \\
\cline { 2 - 9 }
\end{tabular}

\subsubsection{Soil Erodibility Factor (K)}

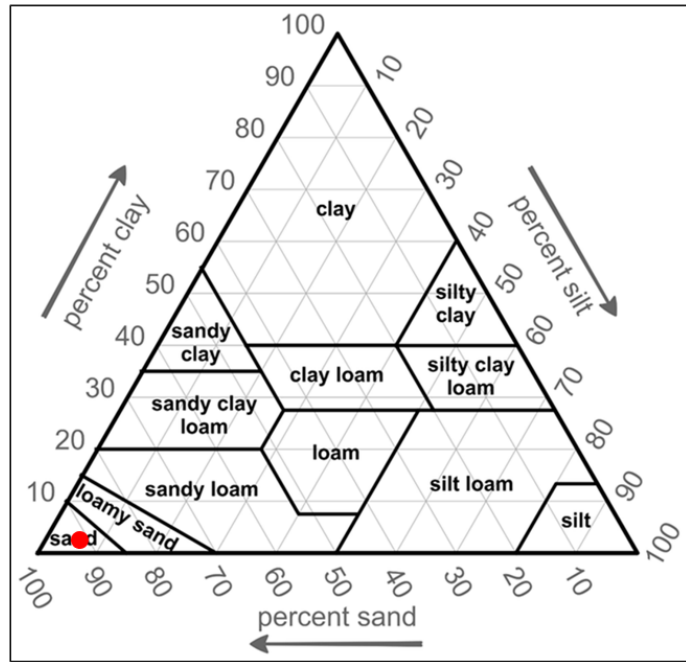

Figure 4. USDA Soil Texture Triangle

Grain size distribution analysis was carried out to identify the soil type at the construction site. The percentages of gravel, sand, silt, and clay were found to be $11.31 \%, 80.25 \%, 7.91 \%$, and $0.53 \%$, respectively. The percentages of sand, silt, and clay were input into the USDA Soil Texture Triangle, and it was found that the soil at the construction site at Curtin University Malaysia was classified as sand as illustrated in Figure 4. Two soil samples were used for organic content tests. The organic matter in the soil was ignited under $440^{\circ} \mathrm{C}$ until the soil was completely ashed. The organic content of two samples was recorded at $2.50 \%$ and $2.74 \%$, 
averaging $2.62 \%$. The soil samples consist of the majority of soil particles with a size of less than $1 \mathrm{~mm}$, which is classified as very fine granular. The permeability of soil samples was categorized as rapid. Figure 5 shows the soil erodibility nomograph. The information from soil samples such as sand percentage, organic content, soil structure, and permeability were input nto the nomograph to obtain the soil erodibility factor. The soil erodibility factor, $\mathrm{K}$, was found to be 0.34 tons $/ \mathrm{hr} / \mathrm{MJ} / \mathrm{mm}$.

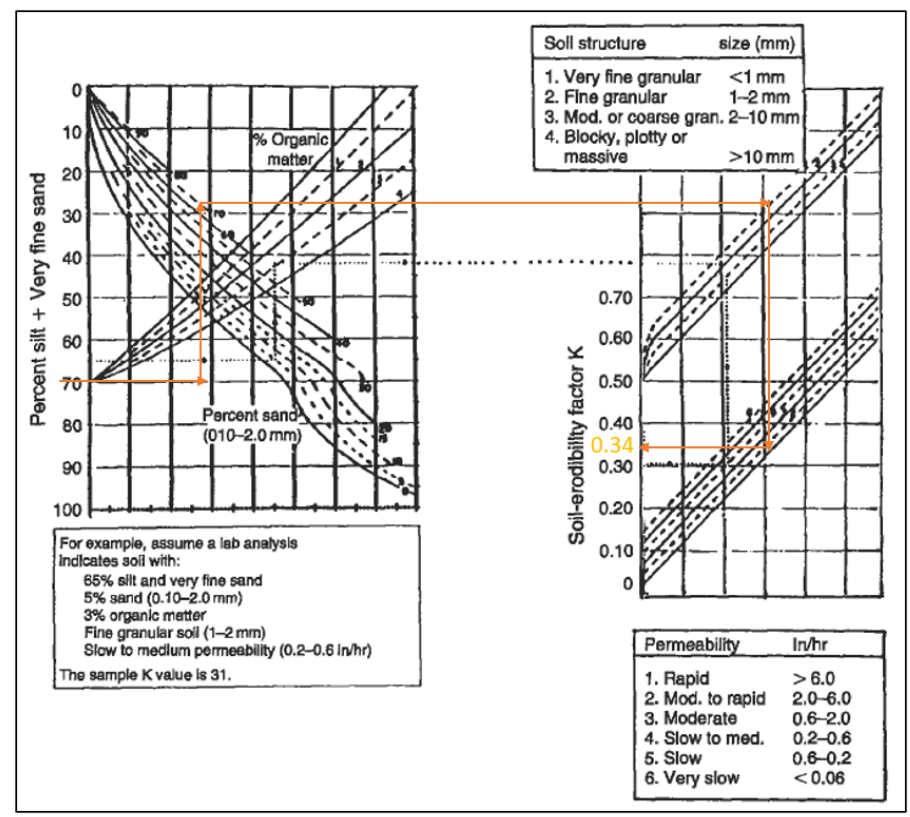

Figure 5. Soil Erodibility Monograph [25]

\subsubsection{Slope Length Factor (L) \& Slope Steepness Factor (S)}

The measurement of the horizontal slope is $109.13 \mathrm{~m}$ while the height is $1.50 \mathrm{~m}$. The horizontal distance of the slope, $\lambda$ was $358.04 \mathrm{ft}$ and the slope gradient was $1.37 \%$. By using interpolation, the LS-factor where slope length coupled with slope steepness was found to be 0.30 .

\subsubsection{Cover Management Factor (C) and Support Practice Factor (P)}

In this study, the ground surface of the construction site in Curtin University Malaysia is bare soil and generally flat (no support practice). Therefore both $\mathrm{C}$ - and P-factors were 1.0.

\subsubsection{Soil Loss Estimation}

The parameters of RUSLE can be determined by using the experimental methodology stated previously. The estimation of annual soil loss using RUSLE (As shown in Table 3, $\mathrm{R}=$ 1176.13MJ mm ha-1 yr-1; $\mathrm{K}=0.34$ ton hMJ-1 mm-1; $\mathrm{LS}=0.30 ; \mathrm{C}$ and $\mathrm{P}=1)$. The amount of soil loss at the construction site at Curtin University Malaysia was estimated at 119.97 tons/ha/year.

Table 3. Estimation of Soil Loss by Using RUSLE

$$
\boldsymbol{A}=\boldsymbol{R K} \boldsymbol{L S C P}
$$

\begin{tabular}{cccccc}
\hline $\mathbf{R}$ & $\mathbf{K}$ & $\mathbf{L S}$ & $\mathbf{C}$ & $\mathbf{P}$ & $\mathbf{A}$ \\
\hline $1176.13 \mathrm{MJ} \mathrm{mm} \mathrm{ha}^{-1} \mathrm{yr}^{-1}$ & 0.34 ton.hr/MJ/mm & 0.30 & 1.0 & 1.0 & 119.97 tons/ha/year \\
\hline
\end{tabular}


There are some studies using RUSLE to estimate annual soil loss carried out in other places of Malaysia. There was an estimated 92.54 tons/ha/year of soil loss estimated in Penang Island, whereas there was 883 tons/ha/year of soil loss in Seremban [32, 33]. In comparison to Curtin University, annual soil loss in Penang Island is lower but Seremban is higher. Based on the case study in Penang Island, huge areas with different land uses (water bodies, urban settlements, forest, agriculture, bare land, and soil erodibility factors are involved. Penang Island owns land with $\mathrm{C}$ varying from 0 to 1 , while most of the land has 0.001 to 0.004 [32]. On the other hand, Penang Island consists of different types of soil, with the soil erodibility varying from 0.07 to 0.1159 [32]. Similar to Penang Island, the land of Seremban consists of a water body, forest, rural areas, agriculture, open space, and urban. Seremban's open space is the primary source of soil loss (610.11 tons/ha/year) [33]. Besides that, there is a case study that focuses on the small catchment areas in Kuala Kari, Kelantan. Among the catchment areas, the highest soil loss is 1416.9 tons/ha/year, which is much higher than in this case study [34]. The runoff erosivity factor in Kuala Kari is much bigger than Curtin University. Overall, different places under different conditions (e.g. weather, soil type, topographic and land use) are the main factors that result in different results in annual soil loss.

\subsection{Sediment Yield Estimation}

MUSLE is used for the estimation of sediment yield. The highest rainfall depth was $12 \mathrm{~mm}$ recorded by using raingauge, which is equivalent to $0.0393 \mathrm{ft}$. The Rational Method $(\mathrm{Q}=\mathrm{CIA})$ was applied to identify the peak discharge as the area involved is less than $0.8 \mathrm{~km}^{2}$ or 80 hectares (Ha) [32]. The $\mathrm{Q}_{\mathrm{p}}$ was determined at $11.265 \mathrm{ft}^{3} / \mathrm{s}$. The remaining parameters, L-, S-, C, and P-factors, are similar to the RUSLE. The amount of sediment yield at the construction site at Curtin University Malaysia was estimated at 0.76 tonnes/storm event (Table 4). In Kuala Kari, Kelantan, the highest sediment yield is 87.14 tonnes/storm event, which is higher in comparison with this study's case. This is because the V and $\mathrm{Q}_{p}$ are much higher in Kelantan, which are the main factors that affect the outcome of sediment yield [34]. Therefore, all the factors of RUSLE and MUSLE would affect the outcome of soil loss and sediment yield [35].

Table 4. Estimation of Sediment Yield by Using MUSLE

\begin{tabular}{|c|c|c|c|c|c|c|}
\hline \multicolumn{7}{|c|}{$\boldsymbol{S}=\mathbf{1 1 . 8}\left(\boldsymbol{V} \times \boldsymbol{Q}_{\boldsymbol{P}}\right)^{\mathbf{0 . 5 6}} \boldsymbol{K} \boldsymbol{L S C P}$} \\
\hline $\mathbf{V}$ & $\mathbf{Q}_{\mathbf{p}}$ & $\mathbf{K}$ & $\mathbf{L S}$ & $\mathbf{C}$ & $\mathbf{P}$ & $\mathbf{S}$ \\
\hline $0.0393 \mathrm{ft}$ & $11.265 \mathrm{ft}^{3} / \mathrm{s}$ & $\begin{array}{c}0.34 \\
\text { ton.hr/MJ/mm }\end{array}$ & 0.30 & 1.0 & 1.0 & $\begin{array}{c}0.76 \text { tonnes/storm } \\
\text { event }\end{array}$ \\
\hline
\end{tabular}

\section{Conclusion}

The amount of soil loss and sediment yield at the construction site at Curtin University Malaysia were determined. The RUSLE and MUSLE models were applied to determine the amount of soil loss and sediment yield, respectively. Several laboratory experiments such as rainfall harvesting, sieve analysis, hydrometer analysis, Standard Proctor Test (SPT) and organic content test were carried out to obtain the values of the parameters in the RUSLE and MUSLE. The amount of soil loss was approximately 119.97 tons/ha/year and the amount of sediment yield was approximately 0.76 tonnes/storm event. Therefore, the aims of this case study were achieved. Consequently, the rate of soil loss and sediment yield are affected by 
anthropogenic activities. An excessive amount of soil loss raises the landslide problem, which threatens living life, and uncontrolled sedimentation causes flash floods.

\section{Acknowledgments}

The authors thank Curtin University Malaysia for facilitating this study. Collaboration from Jabatan Kerja Raya Sarawak is highly appreciated.

\section{Competing Interest}

There is no competing interest to declare.

\section{References}

[1] Nasir Ahmad, N.S.B.; Mustafa, F.B.; Muhammad Yusoff, S.Y.; Didams, G. (2020). A systematic review of soil erosion control practices on the agricultural land in Asia. International Soil and Water Conservation Research, 8, 103-115. https://doi.org/10.1016/j.iswcr.2020.04.001.

[2] Kim, S.M.; Choi, Y.; Suh, J.; Oh, S.; Park, H.D.; Yoon, S.H. (2012). Estimation of soil erosion and sediment yield from mine tailing dumps using Gis: A case study at the Samgwang Mine, Korea. Geosystem Engineering, 15, 2-9. https://doi.org/10.1080/12269328.2012.674426.

[3] Razali, A.; Syed Ismail, S.N.; Awang, S.; Praveena, S.M.; Abidin, E.Z. (2018). Land use change in highland area and its impact on river water quality: a review of case studies in Malaysia. Ecological Processes, 7, 1-17. https://doi.org/10.1186/s13717-018-0126-8.

[4] Teh, S.H. (2011). Soil Erosion Modeling Using Rusle and Gis on Cameron Highlands, Malaysia for Hydropower Development. Master's Thesis, The School for Renewable Energy Science, Akureyri Iceland.

[5] Doula, M.K.; Sarris, A. (2016). Chapter 4 - Soil environment. In Environment and Development,; Poulopoulos, S.G., Inglezakis, V.J., Eds.; Elsevier: Amsterdam, Netherlands, pp. 213-286.

[6] Arriaga, F.J.; Guzman, J.; Lowery, B. (2017). Chapter 5 - Conventional agricultural production systems and soil functions. In Soil Health and Intensification of Agroecosytems; Al-Kaisi, M.M., Lowery, B., Eds.; Academic Press, Cambridge, USA, pp. 109-125.

[7] Mohammed, S.; Abdo, H. G.; Szabo, S.; Pham, Q.B.; Holb, I.J.; Linh, N.T.T.; Anh, D.T.; Alsafadi, K.; Mokhtar, A.; Kbibo, I.; Ibrahim, J.; Rodrigo-Comino, J. (2020). Estimating human impacts on soil erosion considering different hillslope inclinations and land uses in the coastal region of Syria. Water, 12, 2786. https://doi.org/10.3390/w12102786.

[8] Michalek, A.; Zarnaghsh, A.; Husic, A. (2021). Modeling linkages between erosion and connectivity in an urbanizing landscape. Science of The Total Environment, 764, 144255. https://doi.org/10.1016/j.scitotenv.2020.144255.

[9] Holz, D.J.; Williard, K.W.J.; Edwards, P.J.; Schoonover, J.E. (2015). Soil erosion in humid regions: A review. Journal of Contemporary Water Research \& Education, 154, 48-59. https://doi.org/10.1111/j.1936-704X.2015.03187.x.

[10] Borrelli, P.; Robinson, D.A.; Panagos, P.; Lugato, E.; Yang, J.E.; Alewell, C.; Wuepper, D.; Montanarella, L.; Ballabio, C. (2020). Land use and climate change impacts on global soil erosion by water (2015-2070). Proceedings of the National Academy of Sciences, 117, 21994-22001. https://doi.org/10.1073/pnas.2001403117.

[11] Bashagaluke, J.B.; Logah, V.; Opoku, A.; Sarkodie-Addo, J.; Quansah, C. (2018). Soil nutrient loss through erosion: Impact of different cropping systems and soil amendments in Ghana. PloS one, 13, e0208250-e0208250. https://doi.org/10.1371/journal.pone.0208250. 
[12] Hillel, D. (2005). Water harvesting. In Encyclopedia of Soils in the Environment; Hillel, D., Hatfield, J.H., Powlson, D.S., Rosenzweig, C., Scow, K.M., Singer, M.J., Sparks, D.L.; Eds.; Elsevier, Oxford, UK, Volume 4, pp. 264-270.

[13] Dutta, S. (2016). Soil erosion, sediment yield and sedimentation of reservoir: A review. Modeling Earth Systems and Environment, 2, 123. https://doi.org/10.1007/s40808-016-0182-y.

[14] Behera, M.D.; Tripathi, P.; Das, P.; Srivastava, S.K.; Roy, P.S.; Joshi, C.; Behera, P.R.; Deka, J.; Kumar, P.; Khan, M.L.; Tripathi, O.P.; Dash, T.; Krishnamurthy, Y.V.N. (2018). Remote sensing-based deforestation analysis in Mahanadi and Brahmaputra river basin in India since 1985. Journal of Environmental Management, 206, 1192-1203. https://doi.org/10.1016/j.jenvman.2017.10.015.

[15] Nunes, F.C.; de Jesus Alves, L.; de Carvalho, C.C.N.; Gross, E.; de Marchi Soares, T.; Prasad, M.N.V. (2020). Chapter 9 - Soil as a complex ecological system for meeting food and nutritional security. In Climate change and soil interactions, Prasad, M.N.V., Pietrzykowski, M., Eds.; Elsevier; pp. 229-269.

[16] Esmali Ouri, A.; Golshan, M.; Janizadeh, S.; Cerdà, A.; Melesse, A.M. (2020). Soil erosion susceptibility mapping in Kozetopraghi Catchment, Iran: A mixed approach using rainfall simulator and data mining techniques. Land, 9, 368. https://doi.org/10.3390/land9100368.

[17] Rajbanshi, J.; Bhattacharya, S. (2020). Assessment of soil erosion, sediment yield and basin specific controlling factors using Rusle-Sdr and Plsr approach in Konar River Basin, India. Journal of Hydrology, 587, 124935. https://doi.org/10.1016/j.jhydrol.2020.124935.

[18] Pimentel, D.; Burgess, M. (2013). Soil erosion threatens food production. Agriculture, 3, 443463. https://doi.org/10.3390/agriculture3030443.

[19] Gregersen, B,; Aalbæk, J.; Lauridsen, P.; Kaas, M.; Lopdrup, U,; Veihe, A,; van der Keur, P. (2003). Land use and soil erosion in Tikolod, Sabah, Malaysia. ASEAN Review of Biodiversity and Environmental conservation (ARBEC), 1-11.

[20] Nwe, T.T.; Tokuzo, H. (2010). Sediment transport due to flooding from levee breach: a numerical application of the 2004 Niigata flood. International Journal of River Basin Management, 8, 3-14. https://doi.org/10.1080/15715121003714993.

[21] Jamaludin, N.; Mohammed, N.I.; Khamidi, M.F.; Wahab, S.N.A. (2015). Thermal comfort of residential building in Malaysia at different micro-climates. Procedia - Social and Behavioral Sciences, 170, 613-623. https://doi.org/10.1016/j.sbspro.2015.01.063.

[22] Wong, C.L.; Liew, J.; Yusop, Z.; Ismail, T.; Venneker, R.; Uhlenbrook, S. (2016). Rainfall characteristics and regionalization in Peninsular Malaysia based on a high resolution gridded data set. Water, 8, 500. https://doi.org/10.3390/w8110500.

[23] Omar, M.N.; Rahaman, Z.A.; Hashim, M. (2018). The development of a soil erosion risk map for Perak, Malaysia. International Journal of Academic Research in Business and Social Sciences, 8 , 1127-1142. https://doi.org/10.6007/IJARBSS/v8-i4/4149.

[24] Wang, G.; Gertner, G.; Singh, V.; Shinkareva, S.; Parysow, P.; Anderson, A. (2002). Spatial and temporal prediction and uncertainty of soil loss using the revised universal soil loss equation: A case study of the rainfall-runoff erosivity R factor. Ecological Modelling, 153, 143-155. https://doi.org/10.1016/S0304-3800(01)00507-5.

[25] Renard, K.G.; Foster, G.R.; Weesies, G.A.; McCool, D.K; Yoder, D.C.; (1997). Predicting soil erosion by water: A guide to conservation planning with the Revised Universal Soil Loss Equation (Rusle); United States Government Printing: United States; pp. 15.

[26] Pradhan, B.; Chaudhari, A.; Adinarayana, J.; Buchroithner, M.F. (2012). Soil erosion assessment and its correlation with landslide events using remote sensing data and Gis: A case study at Penang Island, Malaysia. Environmental Monitoring and Assessment, 184, 715-727. https://doi.org/10.1007/s10661-011-1996-8. 
[27] Groenendyk, D.G.; Ferré, T.P.A.; Thorp, K.R.; Rice, A.K. (2015). Hydrologic-process-based soil texture classifications for improved visualization of landscape function. PLOS ONE, 10, e0131299. https://doi.org/10.1371/journal.pone.0131299.

[28] Das, B.M. (2002). Soil mechanics laboratory manual, 6th ed.; Oxford University Press, New York; pp. 81-87.

[29] Briaud, J.L.; Saez, D. (2015). Chapter 9 - Recent developments in soil compaction. In Ground Improvement Case Histories; Buddhima, I., Jian, C., Cholachat, R., Eds,; ButterworthHeinemann: San Diego; pp. 275-308.

[30] Wischmeier, W.H.; Smith, D.D. (1978). Predicting rainfall erosion losses: A guide to conservation planning; Department of Agriculture, Science and Education Administration: United States,; pp. 12-17.

[31] Wischmeier, W.H.; Smith, D.D. (1965). Agriculture Handbook No 282, Rainfall-erosion losses from cropland east of the rocky mountains guide for selection of practices for soil and water conservation; Agricultural Research Service U.S. Department of Agrilculture: United States; pp 8-9.

[32] Pradhan, B.; Chaudhari, A.; Adinarayana, J.; Buchroithner, M.F. (2012). Soil Erosion Assessment and Its Correlation with Landslide Events Using Remote Sensing Data and Gis: A Case Study at Penang Island, Malaysia. Environmental Monitoring and Assessment, 184, 715-727. https://doi.org/10.1007/s10661-011-1996-8.

[33] Ahmed, G.B.; Shariff, A.R.M.; Balasundram, S.K.; Abdullah. A.F.B. (2018). Estimation of Soil Loss in Seremban, Malaysia Using Gis and Remote Sensing Technique. IOP Conference Series: Earth and Environemntal Scinces, 169, 012062.

[34] Al-Ani, I.A.; Hussien, O.A. (2020). Application of USLE and MUSLE models for the assessment of soil loss and sediment yield in Kuala Kari, Kelantan. IOP Conference Series: Materials Science and Engineering, 870, 012090. http://dx.doi.org/10.1088/1757-899X/870/1/012090.

[35] Jainet, P. (2018). Evaluation of the conceptual basis of the rational method. International Journal of Hydrology, 2, 698-702. https://doi.org/10.15406/ijh.2018.02.00145.

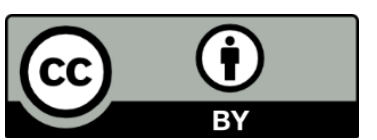

(C) 2021 by the authors. This article is an open access article distributed under the terms and conditions of the Creative Commons Attribution (CC BY) license (http://creativecommons.org/licenses/by/4.0/). 